\title{
The role of fisheries resources in national development: a review
}

\author{
P. D. Rabo, D. U. Zarmai, B. A. Jwanya, S. H. Dikwahal \\ Plateau State College of Agriculture, Garkawa, Nigeria
}

\begin{abstract}
This paper on the role of Fisheries resources in National development is aimed at highlighting the role of Fishery products in Nation building. Fishery products of finned Fish species like Cod, Flounder, Salmon, Catfish, Goldfish, Sea urchins, Shrimps, King crab, Halibut, Mollusk and Echinoderms that come from both capture Fisheries and Aquaculture provide employment, food security, improves welfare, nutrition and a healthy population. Also serve for International trade and foreign exchange in goods like Leather and polishing materials that come from the skin of Cartilagenous Fishes. Ice Fish, dried and canned Fishery products, Salmon roe (egg) and Fish oil used for the manufacture of Soap and Medicinal Oils like the Cod Liver Oil. Fish intake also reduces the condition atherosclerosis thereby combating cardiovascular diseases. However, the Fishery Subsector has some constraints such as by Catch, improper funding, poor input Facilities, Poverty in Fishing Communities, Water barriers, effect of climate change and lack of comprehensive Man power development and training programmes. It is therefore recommended that Government, Donor agencies and international trade unions make effort to increase the educational and capital base of small-scale Farmers; distinguish between Farmed and Wild products, provides Comprehensive Man power and training programmes for all Cadre, providing transportation systems for better appreciation and Productivity in the fishery sub-sector. Laws and by-laws should also be enacted to prevent indiscriminate fishing to avoid over exploitation and extinction of our Aquatic Species.
\end{abstract}

Keywords: Fisheries resources; Aquatic Species; trade; fish's processing

\section{INTRODUCTION}

Fisheries resources are fishery products or output that arises from capture fishery and Aquaculture or Fish farming. Capture fishery comprises resources caught from open Water bodies like Rivers, Lakes, Reservoirs or Dams and Oceans, while Aquaculture or Fish farming is the rearing of fish in an enclosed environment (like Tanks, Ponds, Reservoirs, Dams etc.) which allows free movement, feeding, breeding, and harvesting of fish in a well planned manner. Fisheries resources include familiar finned fish species like Cod, Flounder, Salmon, Ray, Catfish, Tilapia and Gold fish. Others include Mollusk (Oysters and Squid), Crustaceans (Shrimps and Crabs), Echinoderms (Sea Urchins and Star fishes), Jelly fish and sharks.

More than 120 million People throughout the World are estimated to depend on fish for all or part of their income (http;/wif.Jcs.net/icst 2006/jsp files/wif/home.jsp.2006), thereby ensuring food security and raising the protein level of the Nation's populace, and improving their welfare. Fisheries resources are also known to serve for recreation and international 
trade aiding foreign exchange and increasing revenue of a country (Godwin, and James, 1990). Although fishery resources are known to play vital roles in national development, a lot of constraints militate against the fishery subsector. This paper therefore seeks to highlight the roles of Fisheries resources in National development for better appreciation and improved productivity.

\section{GLOBAL PRODUCTION}

Fish farming has been practiced in different parts of the World like Europe, Canada, East Asia, China, Africa and developing Countries like Nigeria (FAO 2009). It has been in practice since the ancient Civilization of Egypt and China. More than 120 Million People throughout the World are estimated to depend on fish for all or part of their income (http/wif.jcs.net/icst 2006/jsp files/wif/home, jsp 2006). Worldwide harvest of fishery products has steadily increased to meet the growing global demand for Sea food (Anderson, 2009). Over 4000 Aquatic species are harvested Worldwide, $80 \%$ of the World's fisheries are located in the Coastal and Ocean environment and nearly $20 \%$ are found in the inland freshwater fisheries. Table 1 shows Commercial catch of fish, Crustaceans and Mollusk by major Fishing areas of the World.

Table 1. Commercial Catch of Fish, Crustaceans, and Mollusk by major Fishing Areas of the World (Metric Tonnes).

\begin{tabular}{|c|c|c|c|c|}
\hline AREA & $\mathbf{1 9 9 1}$ & $\mathbf{1 9 9 5}$ & $\mathbf{2 0 0 1}$ & $\mathbf{2 0 0 5}$ \\
\hline Pacific ocean & $57,085,704$ & $69,376,231$ & $75,121,263$ & $84,233,673$ \\
\hline Atlantic Ocean & $23,730,494$ & $25,437,062$ & $26,813,066$ & $24,044,767$ \\
\hline Indian Ocean & $7,240,806$ & $8,585,803$ & $9,451,755$ & $10,197,402$ \\
\hline Southern Ocean & 411,596 & 147,948 & 120,555 & 146,981 \\
\hline Inland waters & $14,609,309$ & $21,267,338$ & $31,365,668$ & $38,908,390$ \\
\hline Marine areas & $88,468,600$ & $103,547,044$ & $111,506,639$ & $118,622,824$ \\
\hline $\begin{array}{c}\text { Total (marine and } \\
\text { inland waters) }\end{array}$ & $103,077,909$ & $124,814,382$ & $142,872,307$ & $157,531,214$ \\
\hline
\end{tabular}

Source: FAO (2009).

Note: Data do not indicate live weight and do not include marine mammals or aquatic plants.

\section{FISH PRODUCTION IN AFRICA AND NIGERIA}

Fish has existed in Africa since 2000BC (Jim, 2001) and are known as Tropical fishes. Although fish is not a major staple food in the Savanna and highland zones of Africa where 
there is a relatively abundance of Livestock as a source of protein, however, in the tropical Forest margins of the West African coast, fish is a crucial source of protein and the dried form, a common condiment. Over 500,000,000 people in developing countries depend directly or indirectly on fisheries and aquaculture for their livelihood (keith,2010). Principal ground's for marine fishes such as Tuna, Sardines, and Hake are the West African coast from Morocco to Senegal and from Angola and Namibia. The Nile, Niger, Congo, and Senegal River and Lake Victoria, Tanganyika, Malawi and Chad are major source of fresh Water fish. The most common fresh Water catch is the Nile perch.

In 1999, African Fishers caught a total of 6.3 Million metric tons of fish, of which 3.8 Million tons were Marine fish. Morocco, Egypt, South Africa, Ghana and Nigeria were the top African Countries in total fish catch; and Morocco, Namibia, South Africa, Senegal and Libya were the highest exporters of fish. Morocco is also the leader in fish processing industries, producing more canned fish, fish oil, and fish meal than any other African country (Newman et al 2009).

Nigeria's 2005 fish catch was 579,500 metric tons live weight. Slightly less than half the catch was from inland Waters mainly Lake Chad, the Niger Delta and Kainji Lake. The contribution of the fishing sub sector to gross domestic product in Nigeria (GDP) at 2001 rose from 76.76 billion naira to 162.61 billion naira in 2005 (C B N report 2005). Various species of Catfishes, Tilapia, and Nile perch among others are harvested using small scaleand Traditional methods. Sardinellas, Bonga, Shad and Shrimp are harvested from the Atlantic Ocean (Anderson, 2009). Also recent data shows that Nigeria produced just over 600,000 metric tons of fish in 2007, consumer demand on the other hand was reported at 266 million metric tons and was met only in part by imports of about 740,000 metric tons that year (Market resources commodity fact sheet, Nigeria harvest vol. 4. 2007).It has also been reported that Nigeria imports 700,000 metric tons of fish per year to cushion the supplydemand gap (www./cidr.org/yedri.vol1 no .2 and 3,2010).

Fish farming is a vibrant and dynamic commercial sector in Nigeria ripped with investment and employment opportunities. Infact the Aquaculture industry is not new to Nigeria, the first documented fish farm dates back to 50 years. Oladejo (2010) states that Fish production is projected to exceed 150 million tons by the year 2010. Eze and Ogbara (2010) reported that pond fishery is being practiced in Nigeria in large scale for better augmentation of fish products. While the African catfish Clarias gariepinus is widely cultivated in Africa and it is an important commercial mud fish for the Nigerian fishing industry and it is mostly cultivated in KaJola fish farm Ibadan, Nigeria (Fafioye 2011).

\section{ROLES OF FISHERIES RESOURCES IN NATIONAL DEVELOPMENT}

\section{1. Provision of Employment}

With the increase in fish production, employment in fisheries and aquaculture has continued to increase in many countries. Many people had engaged in fishing and fish farming as a full time occupation (Jim 2001). Employment in the primary capture fisheries and aquaculture production sector has remained relatively stable since 1995 and was estimated to be about 35 million in 2000. More than 120 million people throughout the World are estimated to depend on fish for all or part of their income (http./wif.jcs.net/icst 2006/jsp files/wif/home jsp 2006). While over 500 million people in developing countries depend directly or indirectly on fisheries and aquaculture for their livelihoods ( keith, 2010). 


\section{2. Ensure Food Security and welfare of a nation's population}

Fisheries and aquaculture contribute significantly to food security and livelihood. According to Godwin, and James (1990), the United Nation's Food and Agriculture Organization (FAO) opined that global production from capture fisheries and aquaculture is the highest fish supply currently on record and remains very significant for global food security, providing more than $15 \%$ of the total animal protein supplies and at least 50 percent of animal protein and minerals to 400 million people in developing countries (Keith, 2010). China still remains the largest producer with reported fishery production of 41.6 million tons (17 million tons from fisheries and 24.6 million from aquaculture).

The united nation's food and agriculture organization estimated that half of the world's seafood demand will be met by aquaculture in 2020, as wild capture fisheries are over exploited and in decline. Infact, aquaculture production is becoming an essential part of the world's fish supply. The share of the total world's harvest produced through aquaculture has steadily increase over the past two decades and now accounts for nearly $20 \%$ of the world harvest (Anderson, 2009). For instance the Shrimp (or prawn) culture is widespread throughout the world, it is an industry set for a period of strongly growing demand and currently around Us\$ 10 billion (Moriaty 1999).To boost aquaculture therefore, fisheries must depend upon hatcheries where fish reproduction and survival is enhanced to provide the young fish. In Nigeria fish farming is projected to exceed 150 million metric tons by the year 2010 (Oladejo 2010).

The availability of an access to fish within a household can therefore be an important determinant of its Members Wellbeing. At the household level, the consumption pattern may depend on the availability of hard currency, the primary activity of the household and social structures and customs of the people (Ahmed and Krishen 2007).

\section{3. Improvement of the nutritional and health status of a nation's population}

Fish contains a large proportion of protein therefore it is a valuable body building food. Fish is a very important source of complete protein, it is fresh and tender due to bundles of muscle fibres which are tight together by fibrous materials largely made up of a protein called collagen, therefore an excellent dish for the old and diabetic patients. Fish also contains considerable amounts of vitamin B, Vitamin E, nutrients like niacin and minerals such as Copper, Iodine, Iron, and Phosphorus. Canned Salmon and Sardines are good sources of Calcium. Fish make a vital contribution to survival and health of a significant portion of the World's population. In some Asia's poorest Countries, people derive as much as $75 \%$ of their daily protein from fish (Ahmed, and Krishen, 2007).

Meat and fish are an integral part of the diet of Nigerian people and are considered to be essential protein food also serving as focal point for the family meal (Eliol, and Ezenwa, 1988). Fish alone account for about $35 \%$ of animal protein in Nigeria (Market resources 2009). In rural and fishing communities in Nigeria, fish is known to play a significant role in the diet providing up to $75 \%$ of the total animal protein intake. The nutritional value of fish and meat in terms of both protein and micro-nutrients in child development is well documented (Addis 2004). For instance aiding in bone and teeth formation, also combating malnutrition. Cod liver oil is of high medicinal value in children.

Eating deep sea fishes like Tuna and Salmon are highly valued for their cholesterol removing abilities, thereby preventing the condition atherosclerosis In fact, supplementation of omega 3 polyunsaturated fatty acids prevents increase in arterial stiffness especially in post menopause women with coronary artery diseases. Also vitamin E not only helps in the 
elimination of cholesterol and prevents inflammation, It also increases the flexibility and fluidity of your blood vessels so that they respond well to any change of pressure (Erkkila, et al, 2004 and Cardiovase, 2013) thereby reducing the risk of cardiovascular diseases. Atherosclerosis is a condition in which cholesterol, calcium and biochemical waste are deposited as plaques on the inner walls of blood vessels, causing vessels walls to thicken and become rigid and so restricting blood flow and makes blood vessels much more brittle.

Through fish farming, dangers post by standing water bodies can be prevented by keeping the water clean and getting rid of vegetation. Tregakis, (2012) states that the bass and blue fish in ponds are predators of mosquitoes, insect Larvae and Algae helping to keep population in balance. Also the bottom dwelling darter thrives on small snails and insect Larvae, thereby keeping vectors borne diseases in check.

\section{4. Fisheries Resources in International Trade and Foreign Exchange}

Fish products are among the most widely traded foods, with more than $37 \%$ (by volume) of world production traded internationally (FAO 2009). Godwin, and James, (1990) reported that international trade in fish production has increased to a new record of US $\$ 55.2$ billion, continuing the last decade accounting for over $4 \%$ annual growth in fisheries trade. The net export trade from the developing countries increased from $\$ 10$ billion in 1990 to $\$ 18$ billion in 2000 . The increasing demand for sea food has led to a complex global system of trade in the fisheries products. Japan is the largest importer (Anderson 2009). Some fishery products exported by countries include-dried fish, fresh or ice fish, canned fish products, Salmon roll (eggs) and sea urchin roll and shrimps. Others include useful leather and polishing materials and oil made from the skin of some cartilagenous fishes (e.g chondrich thyes like dog fish shark).

Nigeria in the last decades has exported an average of 1500-2000 tons of shrimps annually and 5 tons of smoked fish alone. The peak was at about 14,700 tons in 1992 with exploitation of foreign water arising from bilateral fishing rights agreement being reached with our friendly nations. Through this, a lot is being earned as foreign exchange which is used for national development. An average revenue of about 2.6 billion is been realized from issuance of industrial license in 1992 alone, the estimated aggregate investment in sea fishing crafts an gears at 1992 is about 4.0 billion (Ayodele, and Fregene, 2002).

\section{5. Fishery Products in Recreation}

Fishes are Ornamental as they are kept for beauty and recreation. With their irradescent and under mystique fins, fish add flash and function to backyard aquatic features (Tregaskis 2012). Fishes kept in aquaria also add beauty to offices and laboratories. They are used in schools and colleges for learning. Some ornamental exotic fishes include the Japanese koi fish and Gold fish, which are kept for their attractive colours. Also for years, pond owners have been adding beautiful fishes to their ponds for enjoyment and relaxation of observers (http; /www. Pond trade mag.com/articles/ar-3/2007).

Ornamental fish farming has contributed in trade. Infact, all countries of the European union are a large market for ornamental fishes (www.ava.gov.sgl./ornamental fish FA124/; 2007). The ornamental fish industry is also developing in Nigeria and has reached an appreciable level in Lagos as it is involved in the export of locally bred species (www.Uniportjournals.com/ajazeb.info/2007/46). 


\section{CONSTRAINTS TO DEVELOPMENT OF FISHERY RESOURCES}

Although fishery resources are known to play vital roles in national development, a lot of constraints militate against the achievement of rapid development of the fishery sub sector. Among such factors are:

\section{1. Poverty}

The skills involved in fisheries are multi-disciplinary and poverty has remained a major constraint to fishery resources development (Binjin, 2008). Ahmed and Krishen (2007) also stated that fishing communities are frequently identified as being among the poorest of the poor of the world, characterized by over-crowded living conditions, inadequate social services, low level of education and lack of skills and assets, particularly land that would permit a diversification of their livelihood. Similarly, Oabokaba et al (2005) opined that most of the fishermen and fish farmers in Lagos state were illiterates and depend mostly on local creditors or middle men for finances. Furthermore, Madfadyen and Coccoron (2002) observed that in developing countries, millions of people live in small scale fishing communities. While it is acknowledged that not all small scale fishers can be assumed to be poor, a large proportion of them are and remain so despite the effort of non- governmental organizations, donor agencies, national and local governments and the communities themselves.

\section{2. Government Policies}

Most government policies are aimed at accelerating growth through technological and infrastructural development, and market led economic policies but are not focused on improving living conditions of the poor, hence the continued level of poverty in small scale fishing communities of the world. This sub sector, therefore, requires a whollistic concern.

\section{3. Climate Change}

Climate change is modifying fish distribution and the productivity of marine and fresh water species. This has impact on the sustainability of fisheries and aquaculture and the livelihood of the communities that depend on fisheries. The effect of sea level rise due to flooding means the coastal fishing communities are in the front line of climate change. While changing rainfall pattern and water use impact negatively on inland (fresh water) fisheries and aquaculture, Keith (2010) states that the increase in green house gas emission (GHGE) has led to changing rainfall patterns, rising ocean temperature and acidification, which has radically altered aquatic ecosystem. For example, marine organisms such as shrimps, oysters, or corals find it difficult to form their shells, and coral reefs which provide habitat for millions of fish species are known to die, thus the entire marine food web is being altered. As a result, the distribution, productivity, and species composition of global fish production is changing, generating complex and inter related impacts on breeding and nursery areas for fish.

The impact of climate change can be addressed through adaptation and mitigation. For example, the restoration of mangrove forest can protect shore lines from erosion and provide breeding grounds for fish. Several international agencies including FAO and World Bank have programmes to help countries and communities adapt to global warming by developing policies to improve the resilience of natural resources through assessment of risk and 
vulnerability by increasing awareness of climate change impact and strengthening institutions such as for weather forecasting and early warning systems.

The World Development Report (2010); development and Climate Change Chapter 111 shows that reducing over capacity in fishing fleets, rebuilding fish stocks and reducing green house gas emission can both improve resilience to climate change and increase economic returns from marine capture fisheries by U S Dollars 50 billion per year..

Other constraints to fisheries include absence of a comprehensive man power development and training programme for all cadre of people in the fishery subsector as fish farming requires proper knowledge of aquaculture, site selection and management skills Culturing of fish in a pond may have problems which can cause a setback to fish production .For instance, inability of the farmer to monitor oxygen level, prevent predators, monitor water quantity, infestation by parasites are some of the Setbacks. Deficiency due to lack of essential elements like Vitamins and Minerals, environmental problems caused by change in acidity and alkalinity of the pond water and water quality should also be Considered (Arrigon, 1998 and Binjin 2008).

Furthermore, by catch, where low graded and unsuitable fish stock are caught, over harvest and indiscriminate fishing leading to over exploitation and extinction of our aquatic species like Swordfish, Blue fin, Salmon, many flat fishes ,barriers across rivers which often have negative impact on the natural fish population and contribute among other factors to diminished abundance, leading to disappearance of some fish species (Garcia and Newton, 1997).

\section{CONCLUSION}

For time immemorial, many Countries of the world, including Nigeria have been involved in fisheries and fishery resources, with more than 120 Million People depending on fish for livelihood and employment. This sub sector is also known to be a staple source of nutrition, Food security, Recreation, and Foreign exchange, contributing greatly to national development. In spite of the above, the fishery sub sector is faced with constraints like poverty in small fishing communities, lack of access roads, barriers across rivers, absence of comprehensive manpower and training programmes for all cadre of people, by catch and over exploitation of the marine ecosystem among others.

\section{Recommendation}

Since Fisheries resources contribute to national development and economic growth, there is need for government, non-governmental organizations, donor agencies and all those concerned to seriously look into the poverty condition of small Fishing communities by providing credit facilities to enable them purchase modern fishing inputs like improved nets and fishing gears. This will also improve their educational levels and their living conditions. The effort of the Federal Government of Nigeria through the Fadama 111 project in local fish production in Plateau state is hereby acknowledged. Government and those concerned should intensify effort to provide manpower development and training programmes for all cadre since the skills needed in fish farming are multidisciplinary.

Even as fishery resources contribute immensely to regional and international trade, it is difficult for international trade statistics to distinguish between wild fishery and farmed fishery. Therefore the need for producer association of countries to keep proper records in response to new environmental and labeling requirements that distinguish between farmed 
and wild products is paramount. Barriers across rivers and fishing communities should also be broken through proper construction of transportation systems to enable communication between fishing communities and market. There is also need for extension workers to enlighten and train our local populace to embark on fish farming. Backyard ponds or stagnant water bodies which serve as breeding ground for vectors could be turned into fish farms or ponds for better productivity.

Government should enact laws and by-laws, adopt policies to reduce indiscriminate and unauthorized fishing which leads to over exploitation and extinction of our aquatic species. For example, the United nation in 2002 sponsored the world submit on Sustainable development and called for restoring Fish stock by 2015 (Anderson 2009). Periodic harvesting of fish should be encouraged. This entails Seasonal fishery openings and closings, and critical habitat areas closures to protect the breeding grounds of threatened fish.

\section{References}

[1] Addis, (2004) in Ahmed Goma and Krishen Rana (2007). Inter-household and Intrahousehold Patterns of Fish and Meat Consumption in Fishing Communities in two States in Nigeria. British Journal of nutrition, pp145-152.

[2] Ahmed Gomma, Krishen Rana (2007). Inter-household and Intra-household Patterns of Fish and Meat Consumption in two states in Nigeria. British Journal of Nutrition, 145-152.

[3] Anderson J. L. (2009). Fisheries. Microsoft Encarta, Redmond, W.A, Microsoft Cooperation 2008.

[4] Arrigon J. C. V., M. W. Dickson (1998). Tilapia: The Tropical Agriculturist. Macmillan Educ. Ltd.

[5] Ayodele I. A., Fregene B. T. (2003). Essentials of Investment in Fish Farming Department of Wild life and Fishers Management of the University of Ibadan.

[6] Binjin, Daniel Nendi (2008). Homestead Fish Farming in a Semi Recirculatory System.

[7] Cardiovase J. (2013). Supplementation of Omega 3 Polyunsatturated Fatty Acid Prevents Increase in Arterial Stiffness. Sage journals, 1; 14-20.

[8] Central Bank of Nigeria (2005). Annual Report and Statement of Account. CBN Pub. Abuja 2005.

[9] Eliol and Ezenwa (1988). In: Ahmed Gomna and Krishen Rana (2007). Interhousehold and Intra-household Pattern of Meat Consumption.

[10] Erkilla A. T, Lichtenstein A. L, Mozaltarian D., Herrington D. M. (2004). Fish Intake Associated Reduced Progression of Coronary Artery Atherosclerosis in Post Menopause Women with Coronary Artery Disease, 2004 American Society for Clinical Nutrition in the American. Journal of Clinical Nutrition. O (2010). Microbial and Physiochemical Characteristics of Fish Pond Water in Ughelli Delta State.

[11] Eze V. C., Ogbara I., International of Current Research 8 (2010) 082-087.

[12] Fafioye O (2011). Preliminary Studies on Water Characteristics and Bacterial Population in High Yield Kajola Fish Ponds. Journal of Agricultural Extension and Rural Development, 3(3); 68-71. 
[13] Food and Agriculture Organisation (2009). Climate Change:Implications for Fisheries and Aquaculture; Overview of Current Scientific Knowledge. Fisheries and Aquaculture Technical Paper, 530, Rome.

[14] Food and Agricultural organization (2009). Farm Pond for Water, Fish and Livelihood, FAO, Rome.

[15] Garcia, and Newton (1997). Current Situation Trends and Prospect in the World Capture Fisheries in Pikich E. L. Huppert D. D. and Sissen Wine Global Trend in Fisheries Management: American Fisheries Society Symposium 20, Bethseda, M.D

[16] Godwin M. C., James R.(1990). Crises in world's fisheries United Nation's Food and Agriculture Organization. http://apsfao.org/default.htm downloaded in 2009. http;/wif-ics.net/icsf 2006/jsp files/wif/home.

[17] Jim Cornish (2001). Species of Fish in the Ocean; Gander Academy. http/ww.cdli.ca/cite/oceanfish.htn. downloaded in 2009.

[18] Keith Brander (2010). Impact of Climate Change on Fisheries. Journal of Marine Systems, 79; 389-402.

[19] Moriaty D. J. W. (1999). Disease Control in Shrimps Aquaculture with P robiotic Bacteria in Microbial Bio-systems; New frontiers. Proceeding of the $8^{\text {th }}$ International Symposium on Microbial Economic Bell C. R. Brylinsky M. Johnson Green P. (eds). Atlantic Canada society for Microbial Ecology, Halifas Canada.

[20] World Bank (2009). World Development Report 2010. Development and Climate Change Chapter 3.

[21] O. A. Davies, E. Jaja, International Letters of Natural Sciences 4 (2013) 10-25. 